УДК 373.3:159.922.74

Л. М. КУЛАКОВА, Р.С. КУЛАКОВ

\title{
ПСИХОЛОГІЧНІ ПРИЙОМИ ФОРМУВАННЯ МОРАЛЬНИХ ЦННОСТЕЙ У МОЛОДШИХ ШКОЛЯРІВ В ПРОЦЕСІ ПОЗАУРОЧНОЇ ДІЯЛЬНОСТІ
}

Стаття присвячена аналізу проблеми формування моральних иінностей у дітей молодшого шкільного віку як однісї з найважливіших у рамках Нової украӥнської школи, де формування в дітей загальнолюдських духовних изінностей та орієнтирів є одним із пріоритетних напрямів. У статті охарактеризовано роль школи у формуванні моральних иінностей особистості, зокрема у процесі позакласної та позаурочної діяльності. Висвітлено роль художньої літератури як одного із найважливіших засобів формування моральних иінностей у молодших школярів. $У$ статті систематизовано прийоми роботи з художнім твором, що спрямовані на формування моральних иінностей у дитини, та здійснено детальний аналіз кожного з них.

Ключові слова: моральні цінності, моральна культура, моральні переконання, моральні почуття, молодші школярі, позаурочна діяльність, художня література.

Статья посвящена анализу проблемь формирования нравственных иееностей в детей младшего школьного возраста как одной из самих важных в системе Новой украинской школь, где формирование в детей общечеловеческих духовных ценностей и ориентиров есть одним из приоритетных направлений. В статье охарактеризировано роль школь в формировании нравственных иенностей личности, в частности, в почессе внекласной и внеурочной деятельности. Освещено роль художественной литературы как одного из самих важных средств формирования нравственных иенностей у младшых школьников. В статье систематизировано приемы работы с художественным произведением, которые влияют на формирование нравственных иенностей у ребенка, и подан детальный анализ каждого из них. 
Ключевые слова: нравственные цуенности, нравственная культура, нравственные убеждения, нравственные чувства, младшые икольники, внеурочная деятельность, художественная литература.

Постановка проблеми. У сучасному суспільстві проблеми морального виховання, моральної культури особистості постають надзвичайно гостро. Адже стало очевидним те, що будь-які порушення або відсутність культури поведінки, недотримання загальноприйнятих етичних норм негативно відображаються як на фізичному та психічному здоров”ї населення, так і на моральному та емоційному стані суспільства вцілому. Цілком очевидним стало усвідомлення того, що формування моральних цінностей школярів мають не менше значення для їх розвитку, аніж знання 3 певних навчальних предметів. Саме тому пріоритетним напрямком Нової української школи є формування в дітей загальнолюдських духовних цінностей та орієнтирів [2].

Формування моральних цінностей - це багатогранний процес, який вимагає цілеспрямованого впливу, морального співвідношення об'єктивного й суб'єктивного чинників у вихованні, постійного врахування (у формах і методах виховної роботи) тих змін, які відбуваються в житті [3, с. 46]. Процес формування моральних цінностей здійснюється в різних формах за допомогою різноманітних психолого-педагогічних методів і виховних засобів. Підкреслимо, що школі належить пріоритетна роль у формуванні моральних цінностей у молодших школярів у позаурочній діяльності. Формування цінностей, побудоване на діалозі, спілкуванні, співробітництві, стає для молодшого школяра значимим і привабливим, а тому й ефективним [5, с. 17].

Аналіз останніх досліджень і публікацій. Проблемі формування моральних цінностей особистості присвячені чисельні філософські, соціологічні, психологічні та педагогічні дослідження. Так, в психології нею займалися Б.Г. Ананьєв, Г.І. Бочкарьова, І.Д. Бех, Л.І. Божович, М.Й. Боришевський, Л.В. Долинська, В.А. Крутецький, О.В. Киричук, С.Д.Максименко, Р.В. Павелків, Л.Е. Орбан, А. В. Петровський, Л.І. Пилипенко, А.М. Прихожан, Л.І. Рувінський, Д.Б. Ельконін, П.М. Якобсон, М.Г. Ярошевський та інші, в педагогіці - В.О. Сухомлинський, М.Г.Стельмахович та інші автори. В їх працях показано, що моральність являє собою суб'єктивноідеальну форму відображення у вигляді уявлень і понять реальних взаємин між людьми, яка регулює моральну сторону діяльності особистості. Моральні цінності особистості як під впливом оточуючого середовища (внаслідок відображення і пізнання реально існуючих взаємин між людьми), так і через освоєння норм, вимог, принципів, ідеалів та ін., відображених у суспільній свідомості.

Формулювання цілей статті. Мета статті полягає у визначенні основних психологопедагогічних прийомів формування моральних цінностей у молодших школярів в умовах позаурочної діяльності.

Виклад основного матеріалу дослідження. Одним 3 найважливіших засобів формування моральних цінностей у молодших школярів є художня література [6, с.35]. Ми вважаємо, що доцільно в позакласну роботу включити прийоми роботи 3 художнім твором, спрямовані на формування моральних цінностей. Перша група прийомів - ті, що сприяють формуванню моральних переконань на основі виявлення ідейного змісту. Починати роботу над формуванням моральних цінностей необхідно 3 формування в молодших школярів знань про моральні цінності й на цій основі переконань, почуття власної гідності. Моральні знання не тільки виробляють у молодших школярів уявлення про норми поведінки, але й про наслідки порушення норм або даного вчинку для оточуючих людей. Прийомами формування моральних переконань можуть бути оцінка (аналіз, обговорення) морального вибору літературного героя при роботі з оповіданнями В. Осєєвої «Сині листи», «Чарівне слово», пояснення причини неправильних, з погляду учня, учинків героя («Відвідала», «До першого дощу», «На ковзанці»), виправдання героя («Добра хазяєчка», «Кривдники»).

Розглянемо перший прийом: оцінка (аналіз, обговорення) морального вибору літературного героя. Прийом спрямований на вироблення в молодших школярів прагнень аналізувати вчинок героя твору, міркувати над моральною стороною його вибору, визначитися у своєму варіанті вибору. Молодшим школярам робота з осмислення чужого й власного вибору, його морально-етичного оцінювання буде посильна й цікава. Як правило, молодші школярі інтуїтивно розуміють, що вибір головного героя 3 погляду моральності правильний або неправильний, але для пояснення їм або не вистачає вербальних засобів (відповідної лексики), або вони схильні додержуватися авторитету, наслідувати приклад, не замислюючись, або можуть бути не розвинені рефлексивні вміння. Так, наприклад, в оповіданні «Блакитні листи» можна запропонувати дітям проаналізувати вчинок Каті й Олени: чому Олена не узяла зелений олівець у Каті, незважаючи на те, що та їй давала, і чи можна назвати дівчаток справжніми подругами після цього випадку. Учневі пропонується оцінити (проаналізувати, обговорити із учителем) вибір літературного героя. Учителем можуть бути 
запропоновані наступні питання: «Чи згідний ти з вибором героя? Чому?», «Який вибір зробив би ти? Чому?». Причому питання задають індивідуально кожному учневі на картках. Він може бути добре вписаний у позакласну роботу, наприклад, літературний брейн-ринг за оповіданнями, казками, де учням буде запропоновано відповісти на запитання за змістом розповідей.

3 метою підготовки молодших школярів до особистісного й життєвого самовизначення в позакласній виховній роботі потрібно регулярно практикувати моральне оцінювання вчинків літературних героїв, тому що саме оцінка, i особливо рефлексивна оцінка вчинку героя (із примірянням на себе), формує систему моральних цінностей, під впливом яких учень надалі вибирає індивідуальний життєвий шлях. Механізм даного явища можна відобразити в такому алгоритмі:

1. Морально-етичне оцінювання вчинку літературного героя (його рефлексивна оцінка).

2. Формування системи моральних цінностей молодшого школяра.

3. Визначення себе, свого «Я» у системі ціннісних орієнтації, власного ставлення до моральних цінностей.

4. Вироблення й усвідомлення власної ціннісної позиції.

5. Вибір майбутнього, стилю життя, власного життєвого шляху.

Пояснення причини неправильних, 3 погляду учня, учинків героя. Даний прийом вимагає, щоб учні проаналізували негативні, з їх точки зору, учинки героїв і спробували знайти їх причину, зрозуміти, чому літературні герої так зробили і як можна було б зробити інакше, щоб уникнути неприємних наслідків. Важливо, щоб учні звернули увагу, що причинами неправильних, поганих учинків героїв $є$ їх черствість, невміння поводитися, неуважне ставлення до навколишніх. Даний прийом спрямований на стимулювання в дітей бажання діяти по-іншому.

Виправдання героя. Не всі герої творів В. Осєєвої здійснюють негативні вчинки через такі якості, як егоїзм, підлість і т.ін. У багатьох героїв наступає «душевне прозріння», автор показує, як герої позбуваються від черствості. Прийом спрямований на те, щоб у школярів виробилося розуміння, який герой заслуговує виправдання, а який - ні. Виправдати можна того, хто розкаявся, зрозумів, що він поводився погано стосовно інших людей. Учні повинні виправдовувати героя, якщо можна знайти виправдання. Так, наприклад, в оповіданні «Бабуся» герой - хлопчик Боря - занадто пізно усвідомив, що був жорстоким до бабусі сталось це лише тоді, коли вона вже вмерла. Смерть бабусі пробудила в душі хлопчика добрі почуття і він вилікувався від черствості. Даний прийом допомагає дітям розгледіти гарні якості в людях, простежити, як герої творів з байдужих і жорстоких перетворюються на уважних і чуйних; зрозуміти, що кожен має право на помилку. Так, наприклад, в оповіданні «Кривдники» учні можуть простежити, як грубіяни, що кривдили хлопчика Толю, змінили своє ставлення до нього (після того, як Толя допоміг їм) й стали з ним дружити. Прийом може сприяти формуванню в дітей співчуття, здатності до емпатії.У позакласній роботі прийом може бути використаний, як у грі-змаганні, (наприклад, хто краще й аргументованіше зможе виправдати героя, котрий помиляється).

Формування моральних переконань як компонента знань на основі виявлення ідейного змісту має досить складну структуру. У якості компонентів Є. Степанова виділяє: 1) знання моральної вимоги (норми, правила поведінки, принципи і т. ін.); 2) знання обгрунтування (аргументації) необхідності відповідності цій вимозі; 3) знання існуючого в суспільстві позитивного ставлення до цього положення. Моральні знання як компонент відповідних видів переконання $є$ підсумком засвоєння індивідом морального досвіду людства, що існує у вигляді відповідних знань [5, с. 49].

Ці вимоги зводяться до таких: 1) звернути увагу учнів на ситуацію, яка носить характер морального конфлікту; 2) допомогти учням у виявленні конфронтуючих у конфлікті сторін; 3) сприяти визначенню дійсних мотивів поведінки героїв, формулюванню тих моральних вимог, які лежать в основі цих мотивів; 4) допомогти виявити авторське обгрунтування того, чому певний літературний герой відповідає тій або іншій моральній вимозі, i, якщо це обгрунтування носить

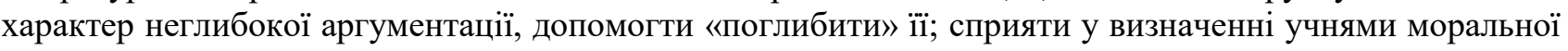
позиції автора в зображуваному конфлікті й у правильній оцінці іiі 3 погляду відповідності прогресивним тенденціям у розвитку моральності; 6) допомогти учням узагальнити моральні вимоги, що розуміються ними у конкретних літературних епізодах [5, с. 61].

При використанні прийомів в учнів сформується здатність не тільки відтворювати моральні знання, як це звичайно буває, якщо вони просто засвоєні, але й бачити в них основу для вибору того або іншого варіанта своєї поведінки, розвивати почуття власної гідності. Така група прийомів спрямована на формування моральних почуттів за допомогою зіставлення почуттів персонажів i власних почуттів читачів. У даній групі ми виділяємо такі прийоми: порівняння власних почуттів 3 почуттями героя твору, добір слів для характеристики персонажів (складання словника почуттів $\mathrm{i}$ 
настрою героя), складання тексту, що розкриває емоційний стан, що виникає при читанні оповідання, написання листа героєві.

Розглянемо перший прийом в цій групі: прийом порівняння власних почуттів з почуттями героя твору. Даний прийом сприяє адекватному оцінюванню своїх почуттів і почуттів героя. Якщо в житті дитини були такі ж ситуації, вона порівнює, які почуття відчував персонаж і які почуття переживала сама дитина в схожих умовах. Щоб краще зрозуміти почуття героя й порівняти їх зі своїми власними відчуттями, учень має зрозуміти причини вчинку героя, осмислити, що його підштовхнуло зробити так, а не інакше, які почуття він при цьому відчував, як би сам учень учинив у даній ситуації. Прийом може сприяти формуванню в дітей емпатії, співчуття, жалю, чуйності, а також здатності поставити себе на місце літературного героя. Згодом це навчить дитину ставити себе на сторону інших людей. Даний прийом може бути вдало включений до позакласної роботи, особливо до виховної години. Наприклад, учні можуть розповідати про свої почуття або індивідуально викладати їх на аркуші, після чого можна організувати колективне обговорення написаного. Учні можуть за бажанням прочитати про свої почуття й емоції.

Другий прийом - добір слів для характеристики персонажів (складання словника почуттів і настрою героя). Метою даного прийому $є$ збагачення словникового запасу дітей словами, що описують моральні почуття героїв твору, і як результат - поява цих почуттів в учнів. Відомо, що збагачення словника словами, що називають почуття, сприяє появі цих почуттів. Можна попросити дітей вести словники, при цьому показати школярам уже готовий словник, як він повинен бути оформлений. У нього учні після прочитання розповідей будуть записувати почуття й настрої героїв твору. Можна запропонувати дітям заповнювати словник як індивідуально (а потім збирати на перевірку), так і колективно (з обговоренням варіантів запису всім класом). Також ефективним для формування моральних почуттів може бути включення в словник не тільки позитивних почуттів, але також і негативних, можна розділити аркуш на дві частини, в одній з яких будуть записуватися позитивні моральні почуття, які переживав герой, а в іншій - негативні. Наступний прийом складання тексту, щзо розкриває емоиійний стан при читанні оповідання. Даний прийом добре поєднується $з$ попереднім. При складанні тексту можна попросити учнів користуватися словником почуттів і настроїв героя. Така робота буде сприяти появі цих почуттів у молодших школярів.

Отже, метою цього прийому $є$ формування моральних почуттів в учнів за допомогою використання в мові слів, що позначають ці почуття. Також прийом спрямований на те, щоб, аналізуючи текст, школярі ще раз відчули той емоційний стан, який переживали під час читання розповіді, і більш повно й чітко вчилися виражати свої почуття. Цей прийом краще використовувати без попереднього обговорення. Варто давати це завдання дітям індивідуально, щоб кожна дитина змогла описати саме свій емоційний стан, а не намагалася скористатися ідеями однокласників.

Прийом «написання листа героєві» також може стати ефективним прийомом формування в молодших школярів моральних почуттів. Можна запропонувати учням написати листа зі словами підтримки або співчуття героєві, що потрапив у біду або зіштовхнувся із проблемами, чи дати пораду героєві, котрий потрапив у складну життєву ситуацію, або ж, навпаки, написати листа негативному персонажу, у якому спробувати пояснити, що він робить недобре, й дати пораду, як треба вчиняти або поводитися в тій або іншій ситуації. Написання листа допоможе дітям краще розібратися у своїх почуттях і зрозуміти ставлення до героя твору. У процесі написання листа діти будуть краще намагатися зрозуміти емоційний стан героїв, ставити себе на їх місце, вчитися аналізувати вчинки й різні життєві ситуації, шукати інші можливі варіанти виходу зі складних ситуацій, можливо згадувати випадки, які відбувалися в їх житті, близькі до тих, у яких опинився герой розповіді. Усе це сприяє формуванню доброти, чуйності, співчуття.

Варто зазначити, що ефективним у процесі роботи 3 формування моральних цінностей $\epsilon$ прийом, спрямований на застосування засвоєних изіностей у поведінці. Шлях від формування у школярів знань про гарну поведінку до здійснення гарних учинків дуже складний. Для цього недостатньо мати знання й переконання про моральні цінності й мати моральні почуття. Необхідно, щоб моральні цінності відображалися у вчинках дитини, щоб вона поводилася відповідно до моральної поведінки. Для цього необхідно створювати (обігравати) ситуації, які близькі до життєвих, щоб у школяра народилися морально-почуттєві переживання, потім виник вольовий стимул і, нарешті, учинок. На це й спрямована наступна група прийомів.

Прийом інсиенування (обігравання) схожих ситуацій. Метою прийому є прояв засвоєних моральних цінностей у поведінці молодших школярів через інсценування (обігравання) ситуацій, схожих на ситуації в тексті. Цей прийом можна використовувати практично в будь-якій формі позакласної роботи (під час виховної години, літературної зустрічі, свята «Доброти», тощо). Також можна програти різні моделі поведінки. Деякі учні обіграють ситуацію, а потім усі разом 
обговорюють і дають поради. Ще один прийом, який може бути ефективним у формуванні моральних цінностей - «роби добрі справи». Після прочитання твору 3 дітьми обговорюється необхідність здійснення гарних, добрих справ. У якості прикладів розглядаються справи, які робили герої оповідей. Потрібно, щоб діти здійснювали добрі справи безкорисливо й засвоїли: «Варто не робити зло, треба робити добро», «Якщо не я це зроблю, то хто?». Можна після прочитання твору обговорити з дітьми, що вони могли б зробити і як учинити в тій або іншій ситуації. Учитель може контролювати, які добрі справи діти роблять, і чи взагалі роблять, шляхом бесіди з батьками, через спостереження. Метою даного прийому є приучення дітей до моральних учинків. Важливо, щоб у дітей був стимул робити добрі справи, щоб діти навчилися вчиняти морально самі, за власною ініціативою, а не на прохання вчителя або батьків.

Висновки 3 даного дослідження і перспективи подальших розвідок у даному напрямку. Ми розглянули прийоми, що сприяють формуванню моральних цінностей молодших школярів у позакласній роботі у процесі знайомства з текстами українських письменників. Ми вважаємо, що дані прийоми будуть ефективними, адже вони базуються на механізмі формування моральних цінностей і передбачають комплексне використання прийомів для формування моральних переконань на основі виявлення ідейного змісту, почуттів за допомогою зіставлення почуттів персонажів та власних почуттів читачів і застосування засвоєних цінностей у поведінці.

\section{Список використаних джерел}

1. Боришевський М. Й. Ціннісні орієнтації в особистісному становленні сучасної молоді / М. Й. Боришевский // Проблеми загальної та педагогічної психології : зб. наук. пр. Ін-ту психології ім. Г. С. Костюка АПН України / за ред. С. Д. Максименка. - Київ, 2003. - С. 34-42.

2. Концепція реалізації державної політики у сфері реформування загальної середньої освіти «Нова українська школа» на період до 2029 року [Електронний документ] : Наказ МОН № 998-р від 14.12.16 p. - Режим доступу : http://osvita.ua>legislation/Ser_osv/54258/.

3. Павелків Р. В. Розвиток моральної свідомості та самосвідомості в молодшому шкільному віці : дис. ... д-ра психол. наук : 19.00 .07 / Р. В. Павелків. - Рівне, 2005. - 455 с.

4. Провоторова В.П. Нравственное развитие младших школьников во внеучебной деятельности / В. П. Проворотова // Начальная школа. - 2011. - № 1. - С. 51-53.

5. Степанова Н. Е. Технология подготовки и проведения личностно-ориентированного классного часа: классному руководителю о классном часе / Н. Е.Степанова; под ред. : Е.Н. Степанова, М. А. Александровой. - М. : Ювента, 2010. - 129 с.

6. Стефаненко Н. А. Нравственно этическая оценка поступка литературного героя / Н. А. Стефаненко, О. Ф. Тульская // Начальная школа. - 2011. - № 11. - С. 34-38.

\section{References}

1. Boryshevskyi M. Y. Tsinnisni oriientatsii v osobystisnomu stanovlenni suchasnoi molodi / M. Y. Boryshevskyi // Problemy zah. ta ped. psykholohii : zb. nauk. pr. In-tu psykholohii im. H. S. Kostiuka APN Ukrainy / za red. S. D. Maksymenka. - Kyyiv, 2003. - S. 34-42.

2. Kontseptsiia realizatsii derzhavnoi polityky u sferi reformuvannia zahalnoi serednoi osvity «Nova ukrainska shkola» na period do 2029 roku [Elektronnyy dokument] : Nakaz MON № 998-r vid 14.12.16 r. - [Rezhym dostupu] : http://(osvita.ua>legislation/Ser_osv/54258/).

3. Pavelkiv R. V. Rozvytok moralnoi svidomosti ta samosvidomosti v molodshomu shkilnomu vitsi : dys. ... d-ra psykhol. nauk : 19.00.07 / R. V. Pavelkiv. - Rivne, 2005. - 455 s.

4. Provotorova V. P. Nravstvennoe razvytye mladshykh shkolnykov vo vneuchebnoi deiatelnosty / V. P. Provorotova // Nachalnaia shkola. - 2011. - № 1. - S. 51-53.

5. Stepanova N. E. Tekhnolohyia podhotovky y provedenyia lychnostno-oryentyrovannoho klassnoho chasa : klassnomu rukovodyteliu o klassnom chase / N. E. Stepanova; pod red. : E. N. Stepanova, M. A. Aleksandrovoi. - M. : Yuventa, 2010. - 129 s.

6. Stefanenko N. A. Nravstvenno эtycheskaia otsenka postupka lyteraturnoho heroia / N. A. Stefanenko, O. F. Tulskaia // Nachalnaia shkola. - 2011. - № 11. - S. 34-38.

Kulakova L., Kulakov R. PSYCHOLOGICAL ADMISSION OF FORMATION MORAL VALUES IN MORE SCHOOLS IN THE PROCESS OF ADVISORY ACTIVITIES.

The article is devoted to the analyzing of the problem of the formation of moral values in the New Ukrainian School. Its main direction is formation children's spiritual values and landmarks. The article is described the role of school in the formation of the individual's moral values particularly in the process of the extracurricular and out of school activities. The role of fiction as one of the most important means of 
formation of moral values in junior pupils is highlighted. The article systematizes the methods of work with the artistic work aimed at forming moral values in the child and detailed analyzed of each of them. The basic psychological and educational aspects in the formation of the children's moral standards on the base of moral concepts, ratings, thinkings and convincings are analysed. The basic categories of the moral standards are determined. The main components which have an impact on the formation of the primary school pupils are characterized and the most important conditions of the positive moral personality developing are determined. The characteristics of the formation of the person's moral standards is investigated and characterized. The importance of the principle of unity of moral state of awareness and moral behavior in the formation of the child's morality is proved. The role of the school in the formation of the person's morality is determined.

Key words: moral values, moral culture, moral convictions, moral feelings, junior pupils, extracurricular activities, fiction. 